\title{
Low-Temperature Sintering of Barium Calcium Zirconium Titanate Lead-Free Piezoelectric Ceramics
}

\author{
John G. Fisher ${ }^{\dagger}$, Dae-Gi Lee, Jeong-Hyeon Oh, Ha-Nul Kim, Dieu Nguyen, Jee-Hoon Kim, \\ Jong-Sook Lee, and Ho-Yong Lee* \\ School of Materials Science and Engineering, Chonnam National University, Gwangju 500-757, Republic of Korea \\ *Department of Advanced Materials Engineering, Sun Moon University,Chungnam 336-708, Republic of Korea
}

(Received November 1, 2012; Revised January 30, 2013; Accepted February 1, 2013)

\begin{abstract}
The need for lead-free piezoceramics has caused a renewal of interest in $\mathrm{BaTiO}_{3}$-based systems. Recently, it was found that ceramics in the $(\mathrm{Ba}, \mathrm{Ca})(\mathrm{Zr}, \mathrm{Ti}) \mathrm{O}_{3}$ system have properties comparable to those of $\mathrm{Pb}(\mathrm{Zr}, \mathrm{Ti}) \mathrm{O}_{3}$. However, these ceramics require rather high sintering temperatures of $1450-1550^{\circ} \mathrm{C}$. In this work, the effect of $\mathrm{TiO}_{2}$ and $\mathrm{CuO}$ addition on the sintering behavior, microstructure, dielectric and piezoelectric properties of $\left(\mathrm{Ba}_{0.85} \mathrm{Ca}_{0.15}\right)\left(\mathrm{Zr}_{0.1} \mathrm{Ti}_{0.9}\right) \mathrm{O}_{3}$ (BCTZ) ceramics will be discussed. BCTZ ceramics were prepared by the mixed oxide route and $1 \mathrm{~mol} \%$ of $\mathrm{TiO}_{2}$ or $\mathrm{CuO}$ was added. Undoped and doped ceramics were sintered at $1350^{\circ} \mathrm{C}$ for $1-5 \mathrm{~h}$. CuO was found to be a very effective sintering aid, with samples sintered for $1 \mathrm{~h}$ at $1350^{\circ} \mathrm{C}$ having a bulk density of $95 \%$ theoretical density; however the piezoelectric properties were greatly reduced, probably due to the small grain size.
\end{abstract}

Key words : Lead-free Piezoceramics, $\mathrm{BaTiO}_{3}$, Sintering, Dielectric Properties, Piezoelectric Properties

\section{Introduction}

B $\mathrm{TiO}_{3}$ was used for acoustic and ultrasonic generation and detection but its low Curie point of $\sim 120^{\circ} \mathrm{C}$ meant that it was quickly superseded by $\mathrm{Pb}(\mathrm{Zr}, \mathrm{Ti}) \mathrm{O}_{3}(\mathrm{PZT}) .{ }^{1)} \mathrm{In}$ recent years, the need for lead-free replacements for PZT has caused a renewal of interest in $\mathrm{BaTiO}_{3}$-based ceramics. Recently, Liu and Ren found that ceramics in the $(\mathrm{Ba}$, $\mathrm{Ca})(\mathrm{Zr}, \mathrm{Ti}) \mathrm{O}_{3}$ system have piezoelectric properties comparable to those of $\mathrm{Pb}(\mathrm{Zr}, \mathrm{Ti}) \mathrm{O}_{3}$, although the Curie point is even lower than that of $\mathrm{BaTiO}_{3}{ }^{2}{ }^{2)}$ The high piezoelectric properties were obtained from compositions close to a triple point between rhombohedral, tetragonal and cubic phases. Unfortunately, these ceramics require rather high sintering temperatures of $1450-1550^{\circ} \mathrm{C}$, $^{3,4)}$ Lowering the sintering temperature would not only reduce production costs, but also raise the possibility of preparing thick film or multilayer co-fired actuators. As of yet, little work has been done on the addition of sintering aids to this system. Chen et al. found that addition of $\mathrm{CuO}$ could lower the sintering temperature to $1400^{\circ} \mathrm{C}$ while retaining good piezoelectric properties. ${ }^{5)}$ In the present work, the effect of $\mathrm{TiO}_{2}$ and $\mathrm{CuO}$ addition on the sintering behavior, microstructure, dielectric and piezoelectric properties of $\left(\mathrm{Ba}_{0.85} \mathrm{Ca}_{0.15}\right)\left(\mathrm{Zr}_{0.1} \mathrm{Ti}_{0.9}\right) \mathrm{O}_{3}(\mathrm{BCTZ})$ ceramics will be discussed.

${ }^{\dagger}$ Corresponding author : John G. Fisher

E-mail : johnfisher@jnu.ac.kr

Tel : +82-62-530-1702 Fax : +82-62-530-1699

\section{Experimental Procedure}

Powders of composition $\left(\mathrm{Ba}_{0.85} \mathrm{Ca}_{0.15}\right)\left(\mathrm{Zr}_{0.1} \mathrm{Ti}_{0.9}\right) \mathrm{O}_{3}$ were prepared using the mixed oxide method. Appropriate amounts of $\mathrm{BaCO}_{3}\left(99.8 \%\right.$, Alfa Aesar), $\mathrm{CaCO}_{3}$ (99.5\%, Alfa Aesar), $\mathrm{ZrO}_{2}$ (99.5\%, Alfa Aesar) and $\mathrm{TiO}_{2}(99.8 \%$, Alfa Aesar) were mixed by ball milling for $24 \mathrm{~h}$ in ethanol using a polypropylene jar and $\mathrm{ZrO}_{2}$ milling media. After ball-milling, the ethanol was evaporated off, the powder crushed in an agate mortar and pestle and sieved to pass a $180 \mu \mathrm{m}$ sieve. Powders were calcined in air in a closed high purity alumina crucible. Calcination temperatures of $1250^{\circ} \mathrm{C}, 1350^{\circ} \mathrm{C}$ and $1450^{\circ} \mathrm{C}$ were used. Calcination time was 5 or $10 \mathrm{~h}$. Heating and cooling rates were $5^{\circ} \mathrm{C} \cdot \mathrm{min}^{-1}$. Calcined powders were examined using X-ray diffraction(XRD, X'Pert PRO, PAN alytical, Almelo, the Netherlands). Additions of $1 \mathrm{~mol} \%$ of $\mathrm{TiO}_{2}$ or $\mathrm{CuO}$ (99.7\%, Alfa Aesar) were made to the powder that had been calcined at $1450^{\circ} \mathrm{C}$ for $10 \mathrm{~h}$ and the doped powders were ball-milled, crushed and sieved as before. An undoped powder was also ball-milled.

To prepare samples for sintering, $0.5 \mathrm{~g}$ of powder was pressed by hand in a $10 \mathrm{~mm}$ diameter steel die. The samples were then cold isostatically pressed at $1500 \mathrm{~kg} / \mathrm{cm}^{2}(147 \mathrm{MPa})$. Samples were placed on a bed of $\mathrm{BaZrO}_{3}$ powder in a double alumina crucible with lids and sintered at $1350^{\circ} \mathrm{C}$ for periods of 1-5 h. Heating and cooling rates were $5^{\circ} \mathrm{C} \cdot \mathrm{min}^{-1}$. Sample density was measured by the bulk method(sample weights and dimensions). The structure of samples sintered for $5 \mathrm{~h}$ was examined using powder XRD. A scan range of $10-80$ degrees $2 \theta$, a step size of $0.013^{\circ}$ and a scan speed of $3.5^{\circ} . \mathrm{min}^{-1}$ was used. Samples sintered for $5 \mathrm{~h}$ were sectioned 
vertically using a low speed diamond wheel saw, polished to a $1 \mathrm{~mm}$ finished and thermally etched at $1250^{\circ} \mathrm{C}$ for $1 \mathrm{~h}$. Samples were $\mathrm{Pt}$ coated and the microstructure examined by scanning electron microscopy(SEM, JEOL JSM-7500F, Tokyo, Japan).

For measurement of Polarization - Electric Field hysteresis loops, silver paste was applied and fired onto both sides of the samples. P-E loops were measured at room temperature using a Sawyer Tower circuit(RT66B combined with 4KV HVI, Radiant Technologies Inc. USA). For measurement of dielectric and piezoelectric properties, Au electrodes were sputtered on both sides of the samples. The samples were poled in silicone oil at $25^{\circ} \mathrm{C}$ under a dc field of $3 \mathrm{kV} / \mathrm{mm}$. The dielectric and piezoelectric properties were measured using an impedance analyzer(Agilent 4294A Precision Impedance Analyzer, USA). $d_{33}$ was measured by a $d_{33}$ meter(APC YE2730A $d_{33}$ Meter, APC International Ltd., USA).

\section{Results}

X-ray diffraction traces of the calcined powders are shown in Fig. 1. All of the patterns can be indexed using JCPDS card \# 01-086-1570 for rhombohedral $\mathrm{BaTiO}_{3}$, space group $R 3 m$. The powder calcined at $1250^{\circ} \mathrm{C}$ for $5 \mathrm{~h}$ contains several secondary phases. Peaks belonging to monoclinic $\mathrm{ZrO}_{2}$ (JCPDS card \# 882390), cubic $\mathrm{ZrO}_{2}$ (JCPDS card \# 98-0105553) and $\mathrm{Ti}_{2} \mathrm{O}_{3}(\mathrm{JCPDS}$ card \# 894746) are present. Repeated ball milling and calcination at $1250^{\circ} \mathrm{C}$ was not effective in removing secondary phases. Increasing the calcination temperature and time leads to a reduction in the amount of secondary phases. However, even after calcination at $1450^{\circ} \mathrm{C}$ for $10 \mathrm{~h}$, a small amount of cubic $\mathrm{ZrO}_{2}$, not easily visible in Fig. 1, remained. Accordingly the powder calcined at $1450^{\circ} \mathrm{C}$ for $10 \mathrm{~h}$ was used for subsequent experiments. Previous workers have also noted the difficulty in preparing single-phase BCTZ powders by the mixed-oxide method. ${ }^{4)}$

The bulk density of BCTZ samples sintered at $1350^{\circ} \mathrm{C}$ for 1-5 h is shown in Fig. 2. For the theoretical density, the cal-

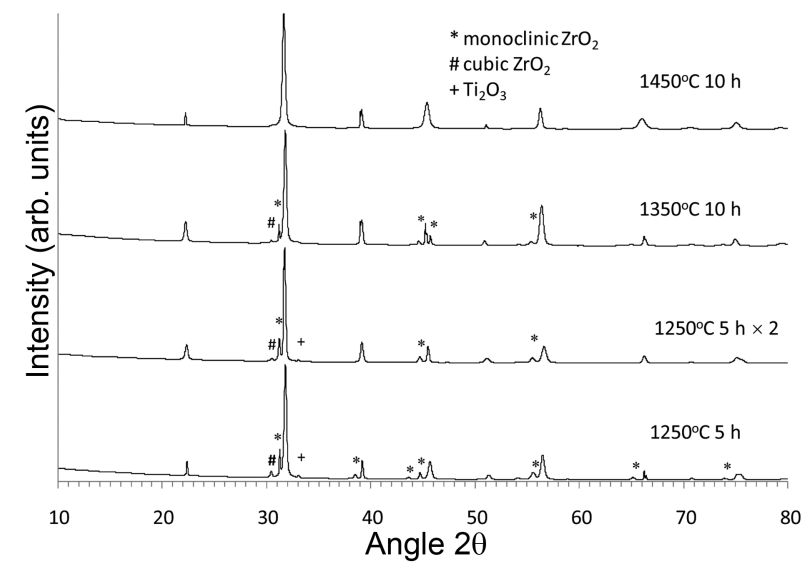

Fig. 1. X-ray diffraction traces of calcined $\left(\mathrm{Ba}_{0.85} \mathrm{Ca}_{0.15}\right)\left(\mathrm{Zr}_{0.1}\right.$ $\left.\mathrm{Ti}_{0.9}\right) \mathrm{O}_{3}$ powders. culated density of $5.687 \mathrm{~g} / \mathrm{cm}^{3}$ for the tetragonal phase was used. ${ }^{4)}$ The density of the undoped samples sintered for $1 \mathrm{~h}$ is very low, only $62 \%$ theoretical density. Increasing the sintering time causes a small increase in density to $66 \%$ theoretical density. For the samples doped with $1 \mathrm{~mol} \% \mathrm{TiO}_{2}$, the density after $1 \mathrm{~h}$ of sintering is the same as for the undoped sample. Further sintering leads to an increase in density to $75 \%$ theoretical density. Addition of $1 \mathrm{~mol} \%$ of $\mathrm{CuO}$ leads to a dramatic increase in density to $95 \%$ theoretical density after only $1 \mathrm{~h}$ of sintering. Further sintering leads to a decrease in density.

XRD traces of the samples sintered at $1350^{\circ} \mathrm{C}$ for $5 \mathrm{~h}$ are shown in Fig. 3(a). A magnified view of the region between $55-80^{\circ} 2 \theta$ is shown in Fig. 3(b). No secondary phases are visible in any of the samples. The undoped sample consists of a rhombohedral phase which can be indexed using JCPDS card \# 01-086-1570 for rhombohedral $\mathrm{BaTiO}_{3}$. Split or broad peaks due to the rhombohedral peak splitting are visible at $66^{\circ}$ and $75^{\circ}$. Addition of $1 \mathrm{~mol} \% \mathrm{TiO}_{2}$ appears to cause a reduction in the rhombohedral peak splitting at $66^{\circ}$. The $1 \mathrm{~mol} \% \mathrm{CuO}$ doped sample can be indexed using JCPDS card \# 89-2475 for cubic $\mathrm{BaTiO}_{3}$. The satellite peaks to the right of the main peaks are due to $\mathrm{K} \alpha_{2}$ splitting. Unit cell parameters were calculated by the least-squares method ${ }^{6)}$ using the computer program MDI Jade 6.5 (Materials Data Inc., California, USA) and are given in Table 1. Addition of $\mathrm{TiO}_{2}$ causes a reduction in the rhombohedral distortion and addition of $\mathrm{CuO}$ causes the structure to change to cubic.

Fig. 4(a) and (b) shows SEM micrographs of undoped and $1 \mathrm{~mol} \% \mathrm{TiO}_{2}$ doped samples sintered at $1350^{\circ} \mathrm{C}$ for $5 \mathrm{~h}$. The undoped sample has equiaxed rounded grains about 0.5-2 $\mu \mathrm{m}$ in diameter. Considerable porosity is visible. The sample

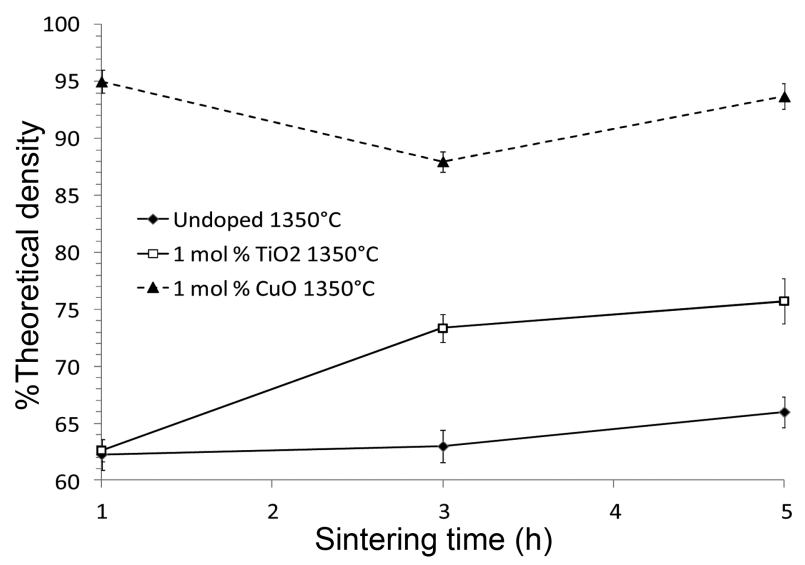

Fig. 2. Bulk density of $\left(\mathrm{Ba}_{0.85} \mathrm{Ca}_{0.15}\right)\left(\mathrm{Zr}_{0.1} \mathrm{Ti}_{0.9}\right) \mathrm{O}_{3}$ ceramics sintered at $1350^{\circ} \mathrm{C}$.

Table 1. Unit Cell Parameters of $\left(\mathrm{Ba}_{0.85} \mathrm{Ca}_{0.15}\right)\left(\mathrm{Zr}_{0.1} \mathrm{Ti}_{0.9}\right) \mathrm{O}_{3}$ Ceramics Sintered at $1350^{\circ} \mathrm{C}$ for $5 \mathrm{~h}$

\begin{tabular}{ccc}
\hline Sample & $\mathrm{a}(\AA)$ & $\beta\left(^{\circ}\right)$ \\
\hline Undoped & $4.00356(0.000245)$ & $89.8638(0.0064)$ \\
$1 \mathrm{~mol} \% \mathrm{TiO}_{2}$ doped & $3.99893(0.000254)$ & $89.9238(0.0055)$ \\
$1 \mathrm{~mol} \% \mathrm{CuO}$ doped & $4.0061(0.000139)$ & 90 \\
\hline
\end{tabular}




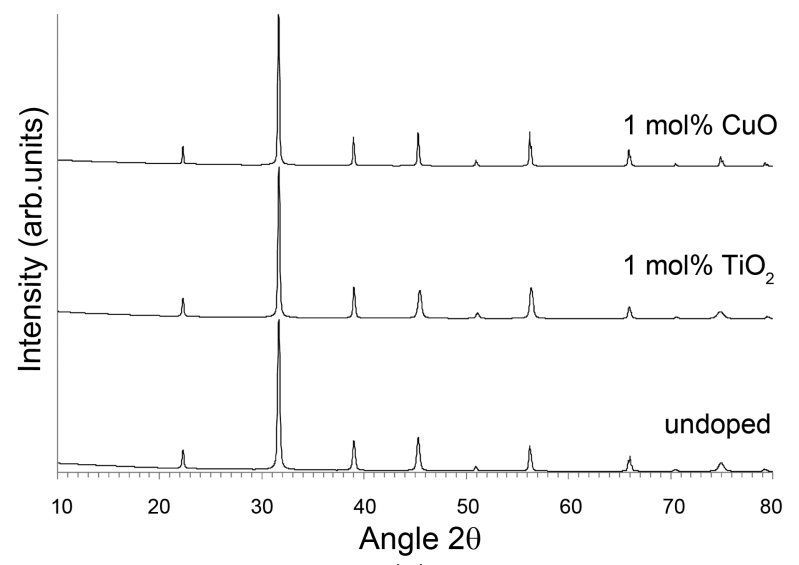

(a)

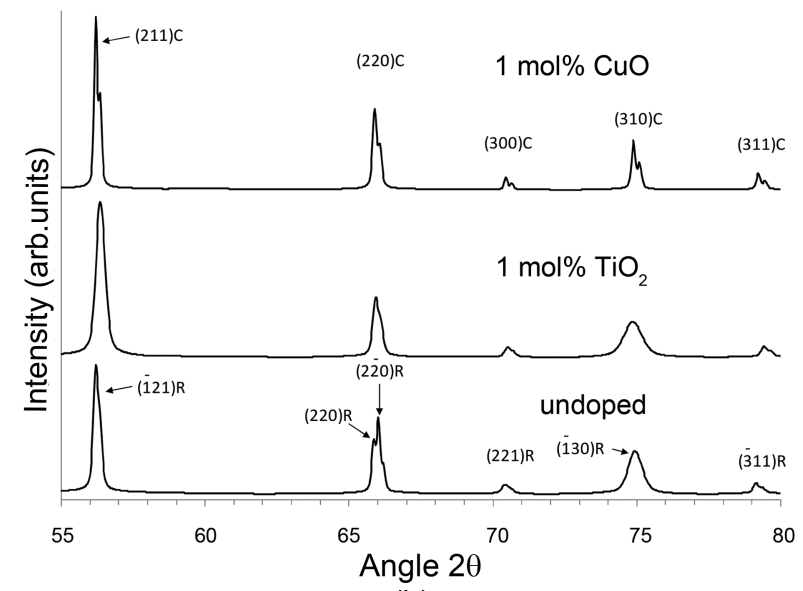

(b)

Fig. 3. (a) X-ray diffraction traces of $\left(\mathrm{Ba}_{0.85} \mathrm{Ca}_{0.15}\right)\left(\mathrm{Zr}_{0.1} \mathrm{Ti}_{0.9}\right) \mathrm{O}_{3}$ ceramics sintered at $1350^{\circ} \mathrm{C}$ for $5 \mathrm{~h}$. (b) Magnified view of the region between $55-80^{\circ} 2 \theta$.

doped with $1 \mathrm{~mol} \% \mathrm{TiO}_{2}$ has smaller grains and smaller pores. Fig. 4(c)-(e) shows micrographs of the $1 \mathrm{~mol} \% \mathrm{CuO}$ doped samples sintered at $1350^{\circ} \mathrm{C}$ for 1,3 and $5 \mathrm{~h}$. The
$1 \mathrm{~mol} \% \mathrm{CuO}$ doped samples have very little porosity. The sample sintered for $1 \mathrm{~h}$ has grains $1-2 \mu \mathrm{m}$ in diameter. The grain size has increased to $2-3 \mu \mathrm{m}$ in diameter for the sample sintered for $3 \mathrm{~h}$, with further sintering causing no further grain growth. The grain shape becomes progressively more cubic as sintering time increases(Fig. 4(e)). Backscattered electron imaging shows that the $\mathrm{CuO}$ doped sample sintered for $5 \mathrm{~h}$ is single phase(Fig. 4(f)).

Due to their low density, the electrical properties of the undoped and $1 \mathrm{~mol} \% \mathrm{TiO}_{2}$ doped samples were not measured. The $P$ - $E$ hysteresis loops for the $1 \mathrm{~mol} \% \mathrm{CuO}$ doped BCTZ ceramic sintered at $1350^{\circ} \mathrm{C}$ for $1 \mathrm{~h}$ are shown in Fig. 5. The legend indicates the maximum electric field for each loop. The loops are narrow and have very shallow slopes, with low values of $\mathrm{P}_{\mathrm{m}}, \mathrm{P}_{\mathrm{r}}$ and $\mathrm{E}_{\mathrm{c}}$. The slope and value of $\mathrm{P}_{\mathrm{m}}$ for the loop with a maximum electric field of $2500 \mathrm{~V} / \mathrm{mm}$ are much higher than that of the other loops. The specimen broke into pieces at electric field of $3000 \mathrm{~V} / \mathrm{mm}$. All of the loops have a pinched appearance; this is more clearly seen in Fig. 5(b), where the $2500 \mathrm{~V} / \mathrm{mm}$ curve has been removed.

The variation of relative permittivity and loss tangent with temperature for the $1 \mathrm{~mol} \% \mathrm{CuO}$ doped BCTZ ceramic sintered at $1350^{\circ} \mathrm{C}$ for $1 \mathrm{~h}$ is shown in Fig. 6. The black arrows show the direction of increasing measurement frequency in the range $0.1-10 \mathrm{kHz}$. The sample shows a broad peak in relative permittivity with a maximum at $53^{\circ} \mathrm{C}$ (Fig. 6(a)). There is no change in the peak temperature with measurement frequency. The value of relative permittivity decreases slightly in the frequency range $0.1-10 \mathrm{kHz}$ and then increases again. The sample had almost identical values of $\varepsilon_{\mathrm{r}}$ at $1 \mathrm{kHz}$ and $100 \mathrm{kHz}$. The sample shows a broad peak in loss tangent at $40^{\circ} \mathrm{C}$, again with no dispersion (Fig. 6(b)). The variation of loss tangent with frequency is identical to that of $\varepsilon_{\mathrm{r}}$. Dielectric, ferroelectric and piezoelectric properties of the sample are given in Table 2. Also shown are the values of Chen et al. for a BCTZ sample doped with $1 \mathrm{~mol} \% \mathrm{CuO}$ and sintered at $1400^{\circ} \mathrm{C}$ for $2 \mathrm{~h}$.

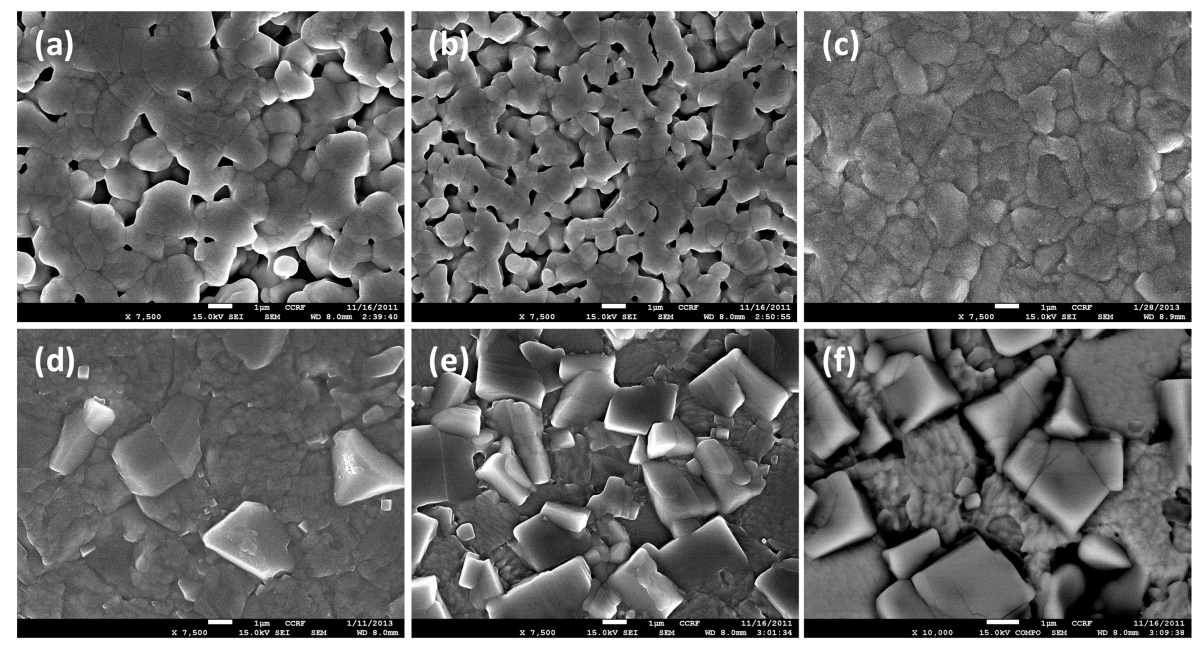

Fig. 4. SEM micrographs of: (a) undoped; (b) $1 \mathrm{~mol} \% \mathrm{TiO}_{2}$ doped $\left(\mathrm{Ba}_{0.85} \mathrm{Ca}_{0.15}\right)\left(\mathrm{Zr}_{0.1} \mathrm{Ti}_{0.9}\right) \mathrm{O}_{3}$ ceramics sintered at $1350^{\circ} \mathrm{C}$ for $1 \mathrm{~h}$ and $1 \mathrm{~mol} \% \mathrm{CuO}$ doped $\left(\mathrm{Ba}_{0.85} \mathrm{Ca}_{0.15}\right)\left(\mathrm{Zr}_{0.1} \mathrm{Ti}_{0.9}\right) \mathrm{O}_{3}$ ceramics sintered at $1350^{\circ} \mathrm{C}$ for: (c) $1 \mathrm{~h}$, (d) $3 \mathrm{~h}$, and (e) $5 \mathrm{~h}$. Fig. $4(\mathrm{f})$ is a backscattered electron image of the sample in Fig. 4(e). 


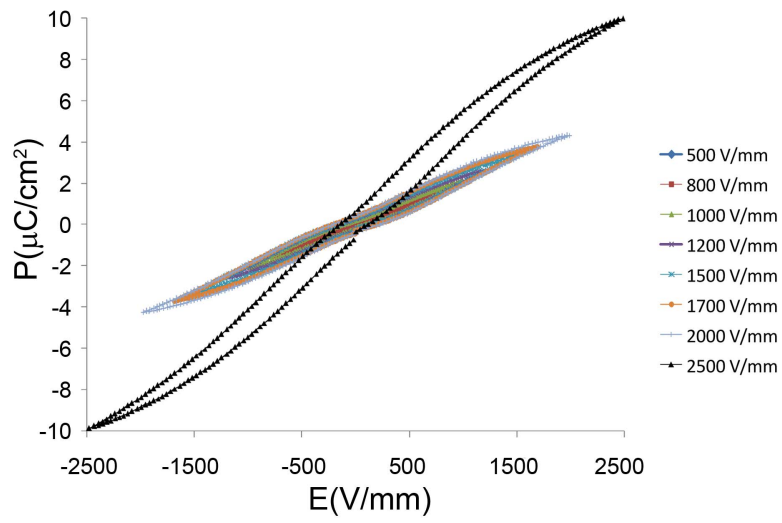

(a)

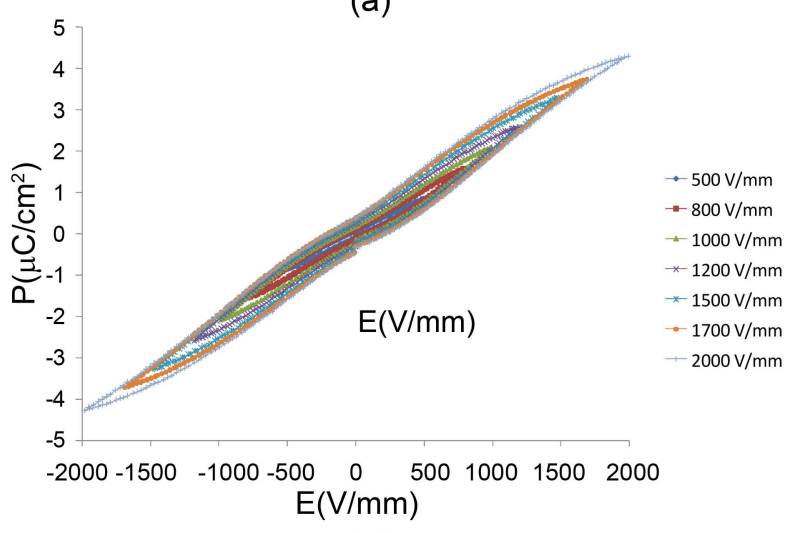

(b)

Fig. 5. (a) $P-E$ hysteresis loops of for $1 \mathrm{~mol} \% \mathrm{CuO}$ doped $\left(\mathrm{Ba}_{0.85} \mathrm{Ca}_{0.15}\right)\left(\mathrm{Zr}_{0.1} \mathrm{Ti}_{0.9}\right) \mathrm{O}_{3}$ ceramic sintered at $1350^{\circ} \mathrm{C}$ for $1 \mathrm{~h}$. (b) hysteresis loops in electric field range $500-2000 \mathrm{~V} / \mathrm{mm}$.

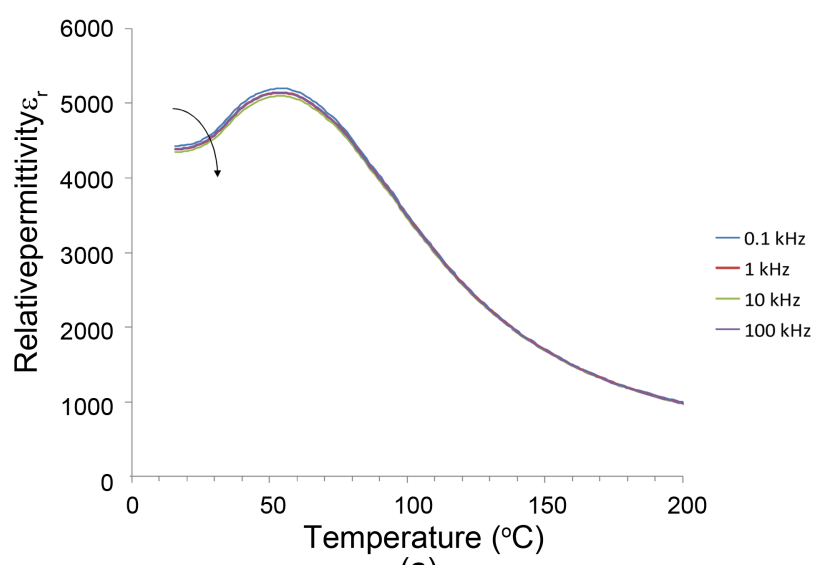

(a)

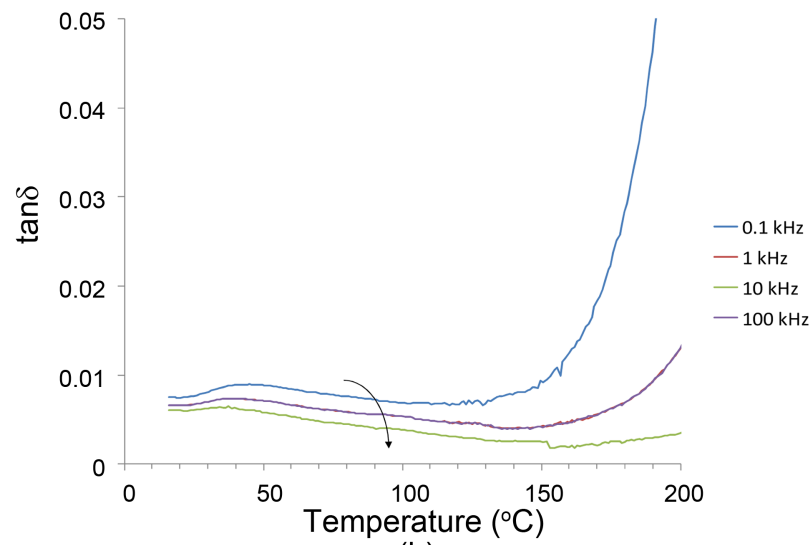

(b)

Fig. 6. Variation of (a) relative permittivity and (b) loss tangent with temperature for $1 \mathrm{~mol} \% \mathrm{CuO}$ doped $\left(\mathrm{Ba}_{0.85} \mathrm{Ca}_{0.15}\right)$ $\left(\mathrm{Zr}_{0.1} \mathrm{Ti}_{0.9}\right) \mathrm{O}_{3}$ ceramic sintered at $1350^{\circ} \mathrm{C}$ for $1 \mathrm{~h}$.

Table 2. Piezoelectric Properties of $1 \mathrm{~mol} \% \mathrm{CuO}$ Doped $\left(\mathrm{Ba}_{0.85} \mathrm{Ca}_{0.15}\right)\left(\mathrm{Zr}_{0.1} \mathrm{Ti}_{0.9}\right) \mathrm{O}_{3}$ Ceramic Sintered at $1350^{\circ} \mathrm{C}$ for $1 \mathrm{~h}$

\begin{tabular}{cccccccccc}
\hline $\begin{array}{c}\varepsilon_{\mathrm{r}} \text { at } 1 \mathrm{kHz} \\
\text { and } 25^{\circ} \mathrm{C}\end{array}$ & $\begin{array}{c}\tan \delta \text { at } 1 \mathrm{kHz} \\
\text { and } 25^{\circ} \mathrm{C}\end{array}$ & $\mathrm{T} \max \varepsilon_{\mathrm{r}}$ & $\mathrm{P}_{\mathrm{m}}\left(\mu \mathrm{C} / \mathrm{cm}^{2}\right)$ & $\mathrm{P}_{\mathrm{r}}\left(\mu \mathrm{C} / \mathrm{cm}^{2}\right)$ & $\mathrm{E}_{\mathrm{C}}(\mathrm{V} / \mathrm{mm})$ & $\mathrm{d}_{33}(\mathrm{pC} / \mathrm{N})$ & $\mathrm{k}_{\mathrm{t}}$ & $\mathrm{k}_{\mathrm{p}}$ & $\mathrm{ref}$. \\
\hline 4450 & 0.007 & $53^{\circ} \mathrm{C}$ & 9.88 & 0.64 & 111 & 72 & 0.112 & 0.113 & This work \\
$\sim 2850$ & $\sim 0.008$ & $\sim 88^{\circ} \mathrm{C}$ & $\sim 15$ & 6 & $\sim 230$ & 350 & - & $\sim 0.4$ & 5 \\
\hline
\end{tabular}

\section{Discussion}

The undoped BCTZ samples showed very poor densification, as expected at the relatively low sintering temperature of $1350^{\circ} \mathrm{C}$. According to the $\mathrm{BaO}-\mathrm{TiO}_{2}$ phase diagram, the solid solubility of $\mathrm{TiO}_{2}$ in $\mathrm{BaTiO}_{3}$ is very limited at the sintering temperature. ${ }^{7,8)}$ The excess titanium reacts with $\mathrm{BaTiO}_{3}$ to form a liquid phase at temperatures $>1332^{\circ} \mathrm{C}$, which may promote sintering. However, substitution of $\mathrm{Ca}$ and $\mathrm{Zr}$ into $\mathrm{BaTiO}_{3}$ may increase the solidus temperature, preventing formation of a liquid phase. ${ }^{9,10)}$ Hence the effect of $\mathrm{TiO}_{2}$ addition on the densification behavior is limited. If $\mathrm{TiO}_{2}$ forms a limited solid solution with BCTZ, then A-site and oxygen vacancies will be required to maintain site and charge balance. These vacancies will increase bulk diffusion rates, which could account for the increased density. ${ }^{11)}$

$\mathrm{CuO}$ melts at $1326^{\circ} \mathrm{C}$ and forms low melting point eutec- tics with $\mathrm{BaO},{ }^{12)} \mathrm{TiO}_{2}{ }^{13)}$ and $\mathrm{ZrO}_{2} \cdot{ }^{14)} \mathrm{CuO}$-based melts are known to be highly wetting of $\mathrm{BaZrO}_{3}$ ceramics. ${ }^{15,16)}$ Therefore, it is expected that the $\mathrm{CuO}$ will react with $\mathrm{BCTZ}$ to form a liquid phase which then wets the particle surfaces and promotes sintering by either contact flattening or pore filling. ${ }^{11)}$ It was previously found that $\mathrm{CuO}$ addition could lower the sintering temperature of $\mathrm{BCTZ}$ to $1400^{\circ} \mathrm{C}^{5)}$; the present work shows that the sintering temperature can be lowered further to $1350^{\circ} \mathrm{C}$ while still maintaining high density.

If $\mathrm{TiO}_{2}$ forms a limited solid solution with BCTZ, then Asite and oxygen vacancies will be required to maintain site and charge balance. This could cause the decrease in the unit cell parameter and the rhombohedral distortion seen in the XRD results(Fig. 3(b) and Table 1). For a coordination number of $6, \mathrm{Cu}^{2+}$ has an ionic radius of $0.073 \mathrm{~nm} . \mathrm{Ti}^{4+}$ and $\mathrm{Zr}^{4+}$ have ionic radii of 0.061 and $0.072 \mathrm{~nm}$ respectively. ${ }^{17)}$ 
Therefore $\mathrm{Cu}^{2+}$ is likely to substitute for $\mathrm{Ti}^{4+}$ or $\mathrm{Zr}^{4+}$ ions in the perovskite lattice. This could cause the slight increase in the unit cell parameter and the change in phase from rhombohedral to cubic, as seen in the XRD results in Fig. 3 and Table 1.

The $\varepsilon_{\mathrm{r}}$ vs. T curve of the $\mathrm{CuO}$ doped BCTZ sample shows a single broad peak with a temperature of maximum permittivity of $53^{\circ} \mathrm{C}$ (Fig. 6). No peak corresponding to a rhombohedral - tetragonal phase change is present, which agrees well with the XRD results (Fig. 3). In the work of Chen et $a l$., $\mathrm{CuO}$ doping appears to change the phase from tetragonal to rhombohedral or cubic, reduces the temperature of maximum permittivity and broadens the $\varepsilon_{\mathrm{r}}$ vs. T peak. ${ }^{5)}$ Hao et al. found that samples with small grain size exhibited more relaxor-like behviour, with broad $\varepsilon_{\mathrm{r}}$ vs. T peaks. ${ }^{18)}$ Similar to the work of Hao et al., our CuO doped BCTZ sample with a small grain size of $\sim 1-2 \mu \mathrm{m}$ shows a broad $\varepsilon_{\mathrm{r}}$ vs. T peak; however there is little dispersion with measurement frequency in our sample. The narrow $P-E$ hysteresis loops indicate that the sample is a relaxor. ${ }^{19)}$ The pinching of the $P-E$ hysteresis loops is likely caused by the interaction of a non-polar phase at temperatures close to the temperature of maximum permittivity. ${ }^{20)}$ The hysteresis loop at $2500 \mathrm{~V} / \mathrm{mm}$ is less pinched and exhibits abruptly higher polarization, which may be interpreted as reversal of the spontaneous polarization of the material. ${ }^{1)}$ The mechanical fracture at the higher field of $3000 \mathrm{~V} / \mathrm{mm}$ also supports the large electrostriction or reverse piezoelectric effect with increased polarization. The dielectric and ferroelectric properties of the sample are somewhat inconsistent. The narrow, pinched P-E loops, the small values of $\mathrm{P}_{\mathrm{r}}$ and $\mathrm{E}_{\mathrm{c}}$, and the broad $\varepsilon_{\mathrm{r}} \mathrm{vs}$. $\mathrm{T}$ peak suggest relaxor behavior, but the $\varepsilon_{\mathrm{r}} \mathrm{vs}$. T peak shows no dispersion with measuring frequency. The reason for this behavior is not yet clear. The relaxor-like behavior of our sample is likely due to a combination of small grain size and the effect of $\mathrm{CuO}$ doping. ${ }^{5,18)}$ Although the $\mathrm{XRD}$ results show a cubic unit cell, the existence of a narrow P-E loop indicates that the unit cell is pseudo-cubic.

In the present work, the piezoelectric properties of the $\mathrm{CuO}$ doped BCTZ samples were found to be poor. The poor properties may be due to the small grain size of $\sim 1-2 \mu \mathrm{m}$ (Fig. 4(c)). Grain boundaries pin domain walls, making it harder to pole the ceramics. A large fraction of the piezoelectric response comes from domain wall contributions i.e. motion of domain walls. ${ }^{21)}$ The contribution of domain wall motion to piezoelectric properties is reduced in fine-grained ceramics, reducing their piezoelectric properties. ${ }^{22,23)}$ Hao et $a l$. recently studied the effect of grain size on the electrical properties of BCTZ ceramics and found a marked decrease in piezoelectric properties as the grain size decreased below $10 \mu \mathrm{m} .{ }^{18)}$ The $\mathrm{CuO}$ doped samples of Chen et al. also had a grain size between $5-10 \mu \mathrm{m}$, even when sintered at $1350^{\circ} \mathrm{C}$. The smaller grain size in the present work is probably due to the larger content of liquid phase sintering aid, $1 \mathrm{~mol} \% \mathrm{CuO}$ as opposed to $0.5 \mathrm{~mol} \% \mathrm{CuO}$ in the work of Chen et al.. The increased volume of liquid phase at the solid/liquid inter- faces increases diffusion distances between grains, reducing grain growth rates. ${ }^{24)}$ As a consequence, the samples of Chen et al. had superior piezoelectric properties to the samples in the present work.

\section{Conclusion}

The effect of $1 \mathrm{~mol} \% \mathrm{TiO}_{2}$ or $\mathrm{CuO}$ addition on the sintering behavior, microstructure and electrical properties of $\left(\mathrm{Ba}_{0.85}\right.$ $\left.\mathrm{Ca}_{0.15}\right)\left(\mathrm{Zr}_{0.1} \mathrm{Ti}_{0.9}\right) \mathrm{O}_{3}$ lead-free piezoelectric ceramics has been studied. Addition of $\mathrm{TiO}_{2}$ caused only a small improvement in the density of samples sintered at $1350^{\circ} \mathrm{C}$. Addition of $1 \mathrm{~mol} \%$ $\mathrm{CuO}$ greatly improved densification, with samples reaching $95 \%$ theoretical density after sintering for $1 \mathrm{~h}$ at $1350^{\circ} \mathrm{C}$. $\mathrm{TiO}_{2}$ addition caused a decrease in the rhombohedral distortion of the unit cell, whereas addition of $\mathrm{CuO}$ caused the structure of $\left(\mathrm{Ba}_{0.85} \mathrm{Ca}_{0.15}\right)\left(\mathrm{Zr}_{0.1} \mathrm{Ti}_{0.9}\right) \mathrm{O}_{3}$ to change from rhombohedral to pseudo-cubic. All of the sintered samples have grain sizes $1-3 \mu \mathrm{m}$. The combination of $\mathrm{CuO}$ doping and small grain size caused the material to show relaxor-like behavior, with a broad $\varepsilon_{\mathrm{r}}$ vs. T peak and narrow, pinched $P$ $E$ hysteresis loops. The piezoelectric properties of the $\mathrm{CuO}$ doped samples were poor, probably due to the small grain size.

\section{Acknowledgment}

This work was funded by Chonnam National University, 2012 and by the Fusion Research Program for Green Technologies through the National Research Foundation of Korea (NRF), funded by the Ministry of Education, Science and Technology (Project No. 2011-0019304). The authors would like to thank Cheol Kim and Seong-Cheon Byeon for operating the XRD and SEM respectively.

\section{REFERENCES}

1. A. J. Moulson and J. M. Herbert, "Chapter 6: Piezoelectric Ceramics," p. 339-410, Electroceramics, 2nd Edition, Chichester, Wiley, 2003.

2. W. Liu and X. Ren, "Large Piezoelectric Effect in Pb-Free Ceramics," Phys. Rev. Lett., 103257602 1-4 (2009).

3. W. Li, Z. Xu, R. Chu, P. Fu, and G. Zang, "Piezoelectric and Dielectric Properties of $\left(\mathrm{Ba}_{1-\mathrm{x}} \mathrm{Ca}_{\mathrm{x}}\right)\left(\mathrm{Ti}_{0.95} \mathrm{Zr}_{0.05}\right) \mathrm{O}_{3}$ Lead-Free Ceramics," J. Am. Ceram. Soc., 93 2942-44 (2010).

4. P. Wang P, Y. Li, and Y. Lu, "Enhanced Piezoelectric Properties of $\left(\mathrm{Ba}_{0.85} \mathrm{Ca}_{0.15}\right)\left(\mathrm{Ti}_{0.9} \mathrm{Zr}_{0.1}\right) \mathrm{O}_{3}$ Lead-free Ceramics by Optimizing Calcination and Sintering Temperature," $J$. Eur. Ceram. Soc., 31, 2005-12 (2011).

5. T. Chen, T. Zhang, G. Wang, J. Zhou, J. Zhang, and Y. Liu, "Effect of $\mathrm{CuO}$ on the Microstructure and Electrical Properties of $\mathrm{Ba}_{0.85} \mathrm{Ca}_{0.15} \mathrm{Ti}_{0.90} \mathrm{Zr}_{0.10} \mathrm{O}_{3}$ Piezoceramics," J. Mater. Sci., 47 4612-19 (2012).

6. B. D. Cullity and S. R. Stock, "Chapter 13: Precise Parameter Measurements," p. 363-84, Elements of X-Ray Diffraction, Third Edition, Prentice-Hall, New Jersey, 2001.

7. D. E. Rase and R. Roy, "Phase Equilibria in the System 
BaO-TiO 2 ," J. Am. Ceram. Soc., 38 102-13 (1955).

8. K. W. Kirby and B. A. Wechsler, "Phase Relations in the Barium Titanate-Titanium Oxide System," J. Am. Ceram. Soc., 74 1841-47 (1991).

9. G. H. Jonker and W. Kwestroo, "The Ternary Systems BaO$\mathrm{TiO}_{2}-\mathrm{SnO}_{2}$ and $\mathrm{BaO}-\mathrm{TiO}_{2}-\mathrm{ZrO}_{2}$," J. Am. Ceram. Soc., 41 39094 (1958)

10. W. Kwestroo and H. A. M. Paping, "The Systems BaO-SrO$\mathrm{TiO}_{2}$, BaO-CaO-TiO, and $\mathrm{SrO}-\mathrm{CaO}-\mathrm{TiO}_{2}$, J. Am. Ceram. Soc., 42 292-99 (1959).

11. S. J. L. Kang, "Chapter 16: Densification Models and Theories,” p. 227-47, Sintering: Densification, Grain Growth \& Microstructure, Elsevier, Oxford, 2005.

12. I. Horsak, J. Sestak, and B. Stepanek, "Simple Computer Program Used for the Calculation of Stable and Metastable Phase Boundary Lines for the Pseudobinary Edges in the $\mathrm{BaO}-\mathrm{CuO}_{\mathrm{x}}-\mathrm{YO}_{1.5}$ System," Thermochim. Acta, 234 233-43 (1994).

13. F. H. Lu, F. X. Fang, and Y. S. Chen, "Eutectic Reaction Between Copper Oxide and Titanium Dioxide," J. Eur. Ceram. Soc., 21 1093-99 (2001).

14. A. M. M. Gadalla and J. White, "Equilibrium Relationship in the System $\mathrm{CuO}-\mathrm{Cu}_{2} \mathrm{O}-\mathrm{ZrO}_{2}$," Trans. Br. Ceram. Soc., 65 383-90 (1966).

15. J. C. Schmidt, A. Tigges, and G. J. Schmitz, "Synthesis of Polycrystalline $\mathrm{BaZrO}_{3}$ Coatings," Mater. Sci. Eng. B, 53 115-18 (1998).

16. A. L. Vinokurov, O. A. Shiyakhtin, Y. J. Oh, A. V. Orlov, and Y. D. Tretyakov, "Comparative Analysis of Barrier Properties of $\mathrm{BaCeO}_{3}$ Ceramics," Supercond. Sci. Technol.,
16 416-21 (2003).

17. R. D. Shannon, "Revised Effective Ionic Radii and Systematic Studies of Interatomic Distances in Halides and Chalcogenides," Acta Cryst., A32 751-67 (1976).

18. J. Hao, W. Bai, W. Li, and J. Zhai, "Correlation Between the Microstructure and Electrical Properties in High-Performance $\left(\mathrm{Ba}_{0.85} \mathrm{Ca}_{0.15}\right)\left(\mathrm{Zr}_{0.1} \mathrm{Ti}_{0.9}\right) \mathrm{O}_{3}$ Lead-Free Piezoelectric Ceramics," J. Am. Ceram. Soc., 95 1998-2006 (2012).

19. Y. Guo, K. Kakimoto, and H. Ohsato, "Ferroelectric-Relaxor Behavior of $\left(\mathrm{Na}_{0.5} \mathrm{~K}_{0.5}\right) \mathrm{NbO}_{3}$-Based Ceramics," J. Phys. Chem. Solids, 65 1831-35 (2004).

20. W. Jo, T. Granzow, E. Aulbach, J. Rodel, and D. Damjanovic, "Origin of the Large Strain Response in $\left(\mathrm{K}_{0.5} \mathrm{Na}_{0.5}\right) \mathrm{NbO}_{3}$. modified $\left(\mathrm{Bi}_{0.5} \mathrm{Na}_{0.5}\right) \mathrm{TiO}_{3}-\mathrm{BaTiO}_{3}$ Lead-free Piezoceramics," J. Appl. Phys., 105094102 1-5 (2009).

21. Q. M. Zhang, H. Wang, N. Kim, and L. E. Cross, "Direct Evaluation of Domain-Wall and Intrinsic Contributions to the Dielectric and Piezoelectric Response and their Temperature Dependance on Lead Zirconate-titanate Ceramics," J. Appl. Phys., 75 454-59 (1994).

22. M. Demartin and D. Damjanovic, "Dependence of the Direct Piezoelectric Effect in Coarse and Fine Grain Barium Titanate Ceramics on Dynamic and Static Pressure," Appl. Phys. Lett., 68 3046-48 (1996).

23. C. A. Randall, N. Kim, J. P. Kucera, W. Cao, and T. R. Shrout, "Intrinsic and Extrinsic Size Effects in FineGrained Morphotropic-Phase-Boundary Lead Zirconate Titanate Ceramics," J. Am. Ceram. Soc., 81 677-88 (1998).

24. J. D. Powers and A. M. Glaeser, "Grain Boundary Migration in Ceramics," Interface Sci., 6 23-39 (1998). 